\title{
APOCALYPSE DERRIDA
}

\author{
BILL MARTIN \\ University of Kansas
}

"Are we to understand the eve as the guard mounted around the house or as the awakening to the day that is coming, at whose eve we are? Is there an economy of the eve?

Perhaps we are between these two eves, which are also two ends of man. But who, we?"

- "The Ends of Man"

"Isn't the voice always that of the last man?"

-"Of an Apocalyptic Tone Recently
Adopted in Philosophy"

"I try to keep myself at the limit of philosophical discourse. I say the limit and not death, for I do not at all believe in what today is so easily called the death of philosophy; (not, moreover, in the simple death of whatever-the book, man, or god, especially since, as we all know, what is dead wields a very specific power)." (Positions, p. 6)

"We must ask ourselves if there is not a recurrent epistemological structure that characterizes all statements made in the mood and the rhetoric of crisis." (Blindness and Insight, p. 14)

"At the very least, to be dead means that no profit or deficit, no good or evil, whether calculated or not, can ever retum again to the bearer of the name. Only the name can inherit, and this is why the name, to be
Can one's memoirs be written by another? If so, that act would certainly qualify as a kind of writing beyond the end of the book. Derrida is much known for his preoccupation with the discourse of ends, in fact several recent pieces play with and on the idea of apocalypse. Derrida deconstructs apocalyptic philosophy and yet is in a sense an apocalyptic philosopher.

A memoir is typically a short, abridged history of oneself, not exactly autobiography. When written by another the plurality of memoirs, of memory, becomes more apparent: "Memories of," "scattered," recollection conscious of dispossession of unified self. In the case of his Memoires for Paul de Man Derrida has subverted the plural not by imposing a unified voice ("he and I were one"), but rather by working through the play of two "individual" voices-the play within each and the play between them, the play in the brisure .

Crisis rhetoric does not play the same role for de Man that apocalyptic discourse does for Derrida. For de Man, the crisis is backdrop to the critical thought of this century (an exemplary case is Husserl's crisis writing). The emphasis is 
distinguished from the bearer, is always and a priori a dead man's name, a name of death. What returns to the name never returns to the living. Nothing ever comes back to the living."

\section{"Politically and}

historically (not just politically, unless one understand "politically" in the broadest sense of the word), it is we who have been entrusted with the responsibility of the signature of the other's lext which we have inherited." (The Ear of the Other , Pp. 7, 51)

"Unlike the other wars, which have all been preceded by wars of more or less the same type in human history (and gunpowder did not mark a radical break in this respect), nuclear war has no precedent. It has never occurred, itself; it is a nonevent. The explosion of American bombs in 1945 ended a "classical," conventional war; il did not set off a nuclear war. The lerrifying reality of the nuclear conflict can only be the signified referent, never the real referent (present or past) of a discourse or text." ("No Apocalypse, Not Now," p. 23)

"Neither God nor the sons of Shem (you know that Shem means "name" and that they bore the name "name") not on the end, or the limit, rather on the permanence of the crisis as a state of flux which all-in-all, once recognized, etc., does not deter philosophers, critics, artists, etc. from carrying out their appointed tasks. Might I suggest that this view has as much to do with temperament as anything? Beyond this likelihood, though, is the greater breadth of Derrida's work-perhaps that is temperament too-the monumental scale of which creates in addition to continental land masses, roiling, stilluncharted seas. Creates them, we sce, as breath out, breath in, and halting stops when breathing is difficult, when late-twentieth century humanity chokes on modernity. (These stops are criticism materialized; these breaths are ... (here the manuscript leaves offl.)

Onecan get away with writing another's memoirs-indeed, why not take the chance? One could even write the history of many-another, also a chance to be taken. What one cannot do and what one must not even attempt to do, is to write the history of everyone, of others in totality: this is not beyond the book, this act closes the book (game over: writing is infinite only under certain circumstances). The moment beyond the end of history does not contain the momarit which is the end of history. (The moment beyond the end of history does not contain the moment which is the end of history.)

Apocalypse, however, is not only the discourse of ends. To think so is perhaps a very recent usage, a post-WWII/pre-WWIII (the precariousness of that slash: as division, as hinge) sense. In "Of an Apocalyptic Tone" Derrida is concerned with apocalypse as that which happens at the end of a certain kind of circuit-something (an historical tradition or trajectory in philosophy, in art, etc.) has run its course-and which reveals, through a kind of retrospection, just what had been going on: what sort of forces and operations were really at work. And, having brought about this sort of revelation, apocalypse revalues human activities and therefore allows new things to begin. For example, 
knew absolutely that they were confronting each other in the name of the name, and of nothing else, thus of nothing. That is why they stopped and moved on to a long compromise. We have absolute knowledge and we run the risk, precisely because of that, of not stopping. Unless it is the other way around: God and the sons of Shem having understood that a name wasn't worth it -and this would be absolute knowledgethey preferred to spend a little more time logether, the time of a long colloquy with warriors in love with life, busy writing in all languages in order to make the conversation last, even if they didn't understand each other too well." ("No Apocalypse" p. 31)

"... the West has been dominated by a powerful program that was also an untransgressible contract among discourses of the end." ("Of an Apocalyptic Tone" p. 80)

"Symbolic condemna. tions, given when they have been official,

"Two years ago on January 28, the space shuttle Challenger exploded seventy-three seconds after liftoff. Despite that disaster,
Wagner's Tristan, in "failing" to resolve its opening chord, ends one sort of tonality and initiales another. Apocalypse, then, is as inuch a discourse of continuity as of ends. Or, as long as apocalypse is a discourse of ends it is not a discourse of the end.

What could be continuous with global nuclear war? What would be revealed? What could beborn?

For some who argue that confrontation is in the cards, the third world war began some years ago. And for some of these, crisis is an everyday condition, practically a lifestyle. They have seen a sign: do not, they have been told and are now telling others, add or take anything away from this letter. Well, what remains to be done, except to repeat this admonition ad infinitum ? The apocalyptic voice does not ask, "what's next?"; "next" is exactly what cannot be: the next of history, of philosophy; the after of teleology and eschatology.

How might we decode the messageto John, "Do not add or take away ..."? Is it not after all a matter of strategies, of battle plans which must not be abridged for to do so would endanger lives? Is it not after all a question of seizing the time, seizing time, stealing the future? Is it not after all a problem of delicate balances, most centrally of competence and incompetence? Who or what rules the balance: is it God or chance? In fact, God is not revealed in the looming apocalypse, though a gaggle of voices proclaim his image in the mushroom cloud. Is this forgery? Forgery would seem to entail a substitution, but why not a substitution of presence for absence (as Lunacharsky had it, "God-building"), a memoir where there was none. There are of course many famous cases of such forged memoirs, almost always linking authenticity (authorship, authority) with property and control. (One would do well, then, to not immediately take such memoirs as gospel.)

Could Derrida represent for us the most extreme communism? For Marx, in socialism property passes from capitalists to the proletariat, and in communism from proletariat to the people in totality (including the "future people," In the sensethis is how Marx has to work the problem out, he cannot afford to simply be moral about this-of the 
however, and despite continuing problems with the shuttle booster rockets, the National Aeronautics and Space Administration plans to launch two space shuttles, one in 1989 and another in 1990, each carrying a space probe utilizing what scientists have called the most toxic substance in the universe: plutonium. Each will contain more than enough plutonium to kill every person on Earth." (The Nation, Jan. 23, 1988)

Which brings up an important consideration concerning the Star Wars program. The idea with SDI is to shoot nuclear missiles down before they can hit their targets and detonate. Assuming the SDI plan could actually work-a proposition which scems highly doubtful-there is still the matter of the unexploded missiles falling to earth and scattering radioactive debris. In the event of a major unleashing of such missiles, this in itself would be enough to kill millions, if not billions, of people-and this aspect of SDI remains completely undiscussed in the mainstream media.

have never disrupled diplomatic, economic, or cultural exchanges, the deliveries of arms, and geopolitical solidarity." ("Racism's Last Word" "people-in-continuity"). Certainly, Derrida's text is in significant part a polemic on property, but also on properties, propricty, the proper (see also de Man in this regard, especially the chapter on Rousscau's Social Contract in Allegories of Reading); does the breadth of his critique make it also a blunted instrument, a flock of missives straying into an array of missiles? Competence being a matter of degree, still: more competent letters fired at incompetent warheads?

Revelation, though, is one thing humanity does have. Assuming an apocalyptic tone, á la the sophists ("mystagogues") chastised by Kant, is one means to subvert systems and to keep the ball rolling (or world turning). It would seem a cardinal principle of intertextuality, however, that the war of words cannot be won, not on/in its own terms anyway. Consider what's typically said about superpower summit meetings: "At least they're talking." The talkers here are truly the mystagogues of which Kant writes. As though the words are the main thing, as though wars are fought over words, and as though wars could be avoided if only the right words could be found.

Derrida, of course, doesn't fall for this line of argument-he is always careful to recognize the interconnecting lines of discourse and the various materialities of discourse. But there is a Derridean argument to be made here: wars may not happen for reasons, but they may happen for Reason. That is, for Kant's Reason, for the foundation, for the logocentric impulse running from Plato to NATO.

Now, what of memory and Reason? In Plato there is of course a very close relation. Everything which one knows is not "found out," not "discovered," rather remembered, uncovered . Clearing away the influence of the appetites, one sees in the pure light of reason the perfect knowledge of which all rational beings are privy. Note, however, that one does not remember the past, rather, one uncovers what is present. Today's imperial logocentrists are not so articulate or inventive-there are no Platos to be found in superpower administrations-but they share this feature with the Socratic doctrine found in the Meno: they remember only the present. Their introspections uncover 
p. 295)

"The anticipation of nuclear war (dreaded as the fantasy, or phantasm, of a remainderless destruction) installs humanity-and through all sorts of relays even defines the essence of modern humanity-in its rhetorical condition. To recall this is not to paint with verbose vanity the horror of the nuclear catastrophe which, according to some, is already degrading our world in its totality, or improving it by the same token, according to others; it is not to say of this absolute pharmakon that it is woven with words, as if we were saying "all this horror is nothing but rhetoric." ("No Apocalypse" p. 24)

In a discussion of Gilles Deleuze, Foucault proposes three theoretical discourses which "fail to grasp the event." For example, philosophy of history: "... it encloses the event in a cyclical pattern of time. Its error is grammatical; it treats the present as framed by the past and future: the present is a former fulure where its form was prepared and the past, which will occur in the future, preserves the identity of its content. First, this sense of the present principles, they remember "Justice," for instance, but never anything so base, so much pertaining to the appetites, as the feel of napalm in the morning. The materiality of the past is indeed a slippery thing, not easily recovered, though. To take a clue from Foucault, the present is no less dense, no more immediate, no less historical. The logocentrists in power have no sense of this density, or, at least, they must suppress all such sense, hiding it even from themselves. There can be no history of the present without history of the past. But a strategy of antilogocentrism cannot simply remind us of the past, though this is hardly unimportant. This is the moment when Derrida tells the Marxists that their problem lies in not having read Heidegger. no history of the past without history of the present. No history without historicity.

Look, then at Derrida's memoirs for de Man. Only occasionally biographical, Derrida's reflections are for the most part deeply theoretical. But then they are reflections upon the life/work of a theorist. Some sort of analogy obtains with the stories we might tell of the planet, its people, its histories. Except that now the shoe is on the other foot: we reflect in a deeply theoretical way on the ways people live and have lived if we are theorists. Our memories, theoretical constructs already, are memories of theory. We possess, then, something of a basic grasp of historicity, the capacity for thinking back through the passageways of reason, and we therefore are partially prepared for a task of future telling and retelling. However, only a third of our work-if that-is done in carrying out this essentially hermeneutic task. Two tasks remain.

First, typical projections, predictions of the future trajectories of Reason, History, Memory as tyrannical emissaries, as non-stratified, non-monumental organizing concepts under the sign of Reason; something about us will have always been the same and will always remain the same. De Man's "Criticism and Crisis" is precisely to this point, and the essay brings out the latent Eurocentrism of the "crisis of Reason" (History, Humanity, etc.) concept. Though talk of the "end of philosophy" may be a bit of a ruse, however, talk of the end of humanity can be deadly serious in the present world situation. Talk 
requires a logic of essences (which establishes the present in memory) and of concepts (where the present is established as a knowledge of the future), and then a metaphysics of a crowned and coherent cosmos, of a hierarchical world." ("Theatrum Philosophicum" pp. 175-76)

"The power of memory does not reside in its capacity to resurrect a situation or a feeling that actually existed, but it is a constitutive act of the mind bound to its own present and oriented toward the future of its own elaboration." (Blindness and Insight, p. 92; cited in Derrida, Memoires, p. 59)

"Memory'... Is first the name... of what for us (an "us" which I define only in this way) preserves an essential and necessary relation with the possibility of the name, and of what in the name assures preservation." (Memoires, p. 49)

"... if there are wars and a nuclear threat, it is because 'deterrence' has neither 'original meaning' nor measure. Its 'ogic' is the logic of deviation and transgres sion, it is rheloricalstrategic escalation or it is nothing at all. It gives itself over, by calculalion, to the incalculable, to chance and luck." ". . it is a question here of an necessarily has its teleology: conversations begin and end. Thus another task remains.

Second, then, the work of disruption. Ending with disruption is to my mind the best insurance of not ending, of creating an opening for a writerly or intertextual politics. Not that any insurance policy will do the trick. Some of the current writers on deconstruction write of "disrupting" or "overturning" hicrarchics as though this is a purely rhetorical operation. The claim on my part is not that the rhetorical work is unimportant (though I have a difficult time seeing that some deconstructionists have much grasp of the possible timeframe which may be involved here), rather that this work must be understood as interfaced at every level with other dimensions of the social text.

The trick-it is more art than science-is to disrupt closure. The means are varied: the utopian aspect, for example, cannot be ignored-nor should it be. Writing in the Derridean sense partakes of this utopian aspect in not closing the book of life, not counting all of the names which may be written there (refusal of a certain reading and a certain mathematics, the reading and mathematics of certain(y). Writing is a call to the imagination, not the anti-imaginary reality of The Late, Great Planet Earth . L'Imagination au Pouvoir ? Yes, more than we knew, it is power over/of life and death. Nothing can betaken away, but an addition to revelation is always possible, given the audacity to write the memoirs of another.

"Let me say a word first about speed. At the beginning there will have been speed ... ... and these stakes appear in the experience of a race, or more precisely of a competition. ....... As no doubt we all know, no singleinstant, no atom of our life (of our relation to the world and to being) is not marked today, directly or indirectly, by that speed race."

-"No Apocalypse, Not Now"

Words in blond: "I am Alpha and Omega, the beginning and the end, the first and the last. And, behold, I come quickly; and my reward is with me, 
aleatory element that appears in a heterogenous relation to every possible calculation and every possible decision. That unthinkable element offers itself to (be) thought in the age when a nuclear war is possible: one, or rather, from the outset, some sendings, many sendings, missiles whose destinerrance and randomness may, in the very process of calculation and the games that simulate the process, escape all control, all reassimilation or self regulation of a system that they will have precipitously (too rapidly, in order to avert the worst) but irreversibly destroyed." ("No Apocalypse", p. 29)

"Heidegger reminds us of the fact that Leibnitz, who was the author of the formula of the Principle of Reason (Der Slaz oom Grund ), was also supposed to be the author of insurance, as we know it." ("No Apocalypse", p. 27n) lhere the manuscript leaves off). (Revelation 22: 13, 12)

Discussion; participating were: Bill Martin, Marc Lennox, Rhonda Faber, and Alexis Harrison.

Marc Lennox: I must admit to thinking Derrida somewhat of a sophist, or to use his term, "mystagogue." Mightn't it be said that, fine, Derrida is now polemicizing against nuclear war, and he has shown the warplanners up for incompetent fools, but, on balance, he has also obscured certain central issues which need most to be sharpened to the utmost clarity? And, if anything, it would seem that you have only made the obscure a bit fuzzier.

Bill Martin: Where to begin? It's not clear whether a "satisfactory" response would be more to give an apology for what for shorthand I'll call the"Derridean approach" or to now "come clean" and give the "straight reading." But I won't do either, though l'll be happy to give a "straight" explanation for not going straight. Perhaps this will be acceptable at some level of metasatisfaction. It seems to me that what's most mystifying in the case of attempting to understand the bases for nuclear conflict-and in fact in attempting to understand the workings of contemporary society in anything like a sophisticated fashion-is all the "straight talk," the conventional wisdom which gets dressed up as theory. This is not a time of conventions, at least not when it comes to talk of warfare (and I do agree with Derrida, there isn't "one atom of our lives" which is not touched by what he calls the "speed race"); so, "wisdom," of the diversionary sort that we are espe-

cially used to hearing from the major media is the last thing we need. Even prior to 1945 warfare was beginning to overrun not only conventions, but even any serious talk of conventions. Now, with the nuclear threat exceeding what could even in some extremely non-conventional sense be called "warfare"what are the objectives, strategies, etc.?-it is more than ever necessary to disrupt whatever linguistic conventions, and therefore, certainly, philosophi-

IEditor's Note: The following discussion notes were read as part of the paper presented at the Illinois Craduate Student Conference.l 
cal conventions, that maintain the ruse of "orderly conflict." Here, you see, I am of course following a certain Derridcan convention: "parasitic iscourse." That is, nuclear weapons themselves-and the social systems of which the are an extension; I, like Lenin, follow Clausewitzin this regard-have demanded, possibly more so than even the voice of God could, the transgression of all boundaries which present themselves as conventional, natural, necessary.

Alexis Harrison: Still, there were many parts of your presentation which seemed to me either unnecessarily opaqueor simply botched-well, to lay it on the line, perhaps deliberately botched by a kind of verbal shadow-boxing.

Bill Martin: Yes, well, I did mean to complete my remarks just now with perhaps just a bit of an apology: the clarity I would not hesitate to polemicize against is a certain "hi-tech" resolution (with the double-entendre intended) which, as l've been attempting to say, obscures by its apparent clarity. Perhaps I'm not so far from the kinds of critique of instrumentalism offered by the Frankfurt Schoolor by Heidegger in his essay on technology. But you probably had some more specific problems in mind...

Alexis Harrison: Well, one connection which seemed tenuous to me is the line you draw between a person, namely Paulde Man, or at least the memory of this person, and nuclear war, a war which will involve all persons.

Bill Martin: And all "potential" persons, as well as, in fact, all persons whom have ever lived. For all intents and purposes, the very notion of persons will be erased. History will not only not be, it will not have been. Likewise memory. This is the connection. Or, rather, this is the opening which allows many connections, many of which have not been drawn here today, and many of which I only hinted at (perhaps, no doubt, in a way which was obscure). As you know, memory was an important subject for de Man, especially as it relates to the rhetorical structures of history and temporality. Secondly, the relation between crisis and apocalypse could be traced much further-it's not for no reason that crisis rhetoric has been one of the main currencies of this century. Apocalyptic rhetoric, on the other hand, seems part of a deeper economy. One of the essential problems for radical social theory nowadays is to better situate the economy of modernism within the deep economy of western metaphysics. And, I hasten to add, vice-versa. It may be proposed that the problem of modernity is simply superficial in comparison to the deeper questions of logocentrism and western metaphysics "as a whole." Perhaps so; but I would argue - or at least $I$ put this forward as a very significant possibility-that only through pursuing the former will we come to terms with the latter. This to me is the "Heidegger - Marx question." Third, in linking the writing of a memoir (albeit in this case a somewhat unusual memoir) to the question of writing history (and the future possibilities thereof), I had hoped to draw a line from "a life" to life. Here you might say that I used de Man as a stand-in, in a way not 
so much unfair to de Man as to all who live a singular life. That is, in some sense, all who live life. The line runs in one direction only, from singular life to life, and indeed erases most if not all of what is typically meant by "singular" or "individual" life. Though many questions of contemporary social existenceare enough to suggest this erasure, perhaps none are so persuasive as that of nuclear war.

Rhonda Faber: But, if I could jump in here ... isn't the enormity of this problem exactly what makes it kind of a non-problem? And in that sense, aren't the other problems of, as you call it, "contemporary social existence" reinstated with even greater force?

Bill Martin: I certainly don't intend to minimize the importance of other problems, but perhaps you could say more about nuclear war being a nonproblem?

Rhonda Faber: Sure: to put it crudely, if the bombs go off, we've had it, so there's little sense in worrying about it. I say this not from a cynical or narrow point of view-I'm not proposing that we therefore "party till it's 1999." My point is that all of the noise about something which it seems unlikely that we'll resolve is actually diverting energy away from soluble problems. Don't get me wrong - of course I don't want the world to blow up, but I think that's out of our hands-out of the hands of people like you and meand most "ordinary people." It's even out of the hands of Derrida! Why not deal, then, with problems that ordinary people can have a hand in changing?

Bill Martin: O.K., now I read you: I'm tempted to wonder, should I neither add to or take away from this message? If I may be so bold, I prefer to add-though in so doing $I$ will certainly also take away. There is the sense in which people typically speak of a new world war as something which could happen in the future. Thankfully we still possess that mode of speaking, though $\mathrm{i}$, following Derrida, have attempted to problematize its "sense." In actuality, to be able to speak of World War Three as still in "the future" is the precondition for being able to speak of anything at all. But there is also a sense, to be sure, in which this "next" war has already started, is happening even as we speak. These other problems you allude to are marked by this fact, sometimes in ways that are fairly clear. It is easy enough to see the relation bet ween a superpower's welfare and warfare functions. What has to be uncovered-where we need more revelations-is the relation between this speed race which marks every atom of our lives and the shape of other real questions of contemporary society. To take but one-though it is of course not simply one among many, but quitecentralwhat about all of those issues which are related to gender and the situation of women? Does this war have a gender? Are the many questions of gender now marked by this war? To both questions I offer an immediate "yes." Still, the lines must be traced, and some of the lines are currently being traced through 
investigations which are not necessarily predicated upon there being a link.

Alexis Harrison: So, does the marking give rise to a teleology?

Bill Martin: Of a sort. The nuclear question may be the first true question of the end of history. The desire for there to be, once and for all, such a question, is a very long-standing desire, identified by Freud with the death-wish. Now humanity has simultaneously come into possession of a true teleological question and an "answer." The problem now is, seeing the true shape of that which we so desperately wanted, to back off from this finality and to continue the conversation in other terms. But I see that we' re just about out of time...

\section{Works Cited}

de Man, Paul. Allegories of Reading. New Haven: Yale University Press, 1979.

de Man, Paul. "Criticism and Crisis," in Blindness and Insight. Minneapolis: University of Minnesota Press, 1983; pp. 3-19.

Derrida, Jacques. The Ear of the Other. English edition edited by Christie V. McDonald. Trans. Peggy Kamuf and Avital Ronell. New York: Schocken Books, 1985.

Derrida, Jacques. Memories for Paul de Man. Trans. Cecile Lindsay, Jonathan culler, and Eduardo Cadava. New York: Columbia University Press, 1986.

Derrida, Jacques. "No A pocalypse, Not Now (full speed ahead, seven missiles, seven missives)." Trans. Catherine Porter and Philip Lewis. Diacritics 14.2 (Summer 1984): 20-31.

Derrida, Jacques. "Of an Apocalyptic Tone Recently Adopted in Philosophy." Trans. John P. Leavcy, Jr. Semeia 23 (1982): 63-97.

Derrida, Jacques. Positions. Trans. Alan Bass. Chicago: University of Chicago Press, 1981.

Derrida, Jacques. "Racism's Last Word." Trans. Peggy Kamuf. Critical Inquiry 12.1 (Autumn 1984): 290-299.

Faucault, Michel. "Theatrum Philosophicum," in Language, counter-memory, practice. Trans. Donald Bouchard and Sherry Simon. Ithaca: Cornell University Press, 1977; pp. 165-196. 